Check for updates

Cite this: RSC Adv., 2019, 9, 23400

Received 28th June 2019

Accepted 22nd July 2019

DOI: $10.1039 / c 9 r a 04889 h$

rsc.li/rsc-advances

\title{
Double nucleophilic addition to iminomalonate, leading to the synthesis of quaternary $\alpha$-amino diesters and desymmetrization of the products $\uparrow$
}

\author{
Makoto Shimizu, (iD *ab Miki Mushika, ${ }^{b}$ Isao Mizotab and Yusong Zhu ${ }^{\mathrm{b}}$ \\ Alkylation of iminomalonate with Grignard reagents followed by oxidation and allylation gave symmetrical \\ quaternary $\alpha$-amino diesters in good yields. Subsequent desymmetrization of a diol derivative from these \\ products was conducted via asymmetric carbamylation catalyzed by Cu-Bnbox to give chiral quaternary \\ aminodiol mono-carbamates.
}

\section{Introduction}

Quaternary $\alpha$-amino acid or ester moieties are very important structural units in many biologically active compounds, since the incorporation of rigid amino acid surrogates concerns very useful information on the bioactive conformation and provides intriguing physiological effects. ${ }^{1,2}$ Quaternary $\alpha$-amino acid moieties are also found as fundamental skeletons in medicines and agrochemicals such as Ecteinascidin 743, Salinosporamide A, and Neooxazolomycin (Fig. 1)..$^{3-5}$

However, it is not trivial to construct quaternary $\alpha$ amino acid frameworks in a stereoselective manner. ${ }^{6}$ For the synthesis of $\alpha$-amino acids and their derivatives $\alpha$ imino esters are useful substrates, since $\alpha$-imino esters have a unique reactivity: either $N$ - or $C$-alkylation is possible. Although an umpolung $N$-alkylation reaction of $\alpha$-imino ester is difficult due to the electronegativity of the imino group, it can lead to a flexible introduction of substituents into the nitrogen atom of the amino acid frameworks. ${ }^{7,8}$

We have already reported that umpolung $N$-alkylation reactions of $\alpha$-iminoesters 1 followed by $C$-electrophilic addition or oxidation followed by $C$-nucleophilic addition gives intriguing $\mathrm{N}, \mathrm{C}$-double addition products in good yields with high diastereoselectivities. ${ }^{9}$ In our previous report, we found that a combined use of diethylaluminum chloride and ethylaluminium dichloride promoted most efficiently the $N$-alkylation of $\alpha$-aryl $\alpha$-iminoester 2 , and the subsequent oxidation and allylation were conducted with

${ }^{a}$ School of Energy Science and Engineering, Nanjing Tech University, Nanjing 211816, Jiangsu Province, China

${ }^{b}$ Department of Chemistry for Materials, Graduate School of Engineering, Mie University, Tsu, Mie 514-8507, Japan. E-mail: mshimizu@chem.mie-u.ac.jp

$\dagger$ Electronic supplementary information (ESI) available. See DOI: $10.1039 /$ c9ra04889h benzoyl peroxide and allyltributylstannane, respectively (eqn (1), Scheme 2) ${ }^{9 b}$ During investigations into amination ability of iminomalonate 1 to organometallics, we found that not only organoaluminum compounds but also Grignard reagents were readily aminated to give 2 -aminomalonates in good to high yields (eqn (1), Scheme 1). ${ }^{9 a}$ However, the resulting halomagnesium enolate that was an $\mathrm{N}$-addition intermediate was not used for further $\mathrm{C}-\mathrm{C}$ bond formations. Since the previous study shows that the oxidation of an intermediary $\alpha$-aminoester enolate readily gives an iminium species that is attacked by a nucleophile, the present intermediary halomagnesium enolate is expected to have a similar reactivity.
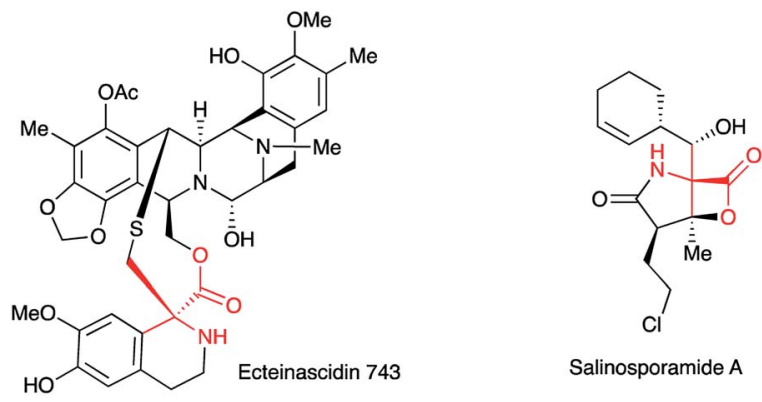

Salinosporamide A

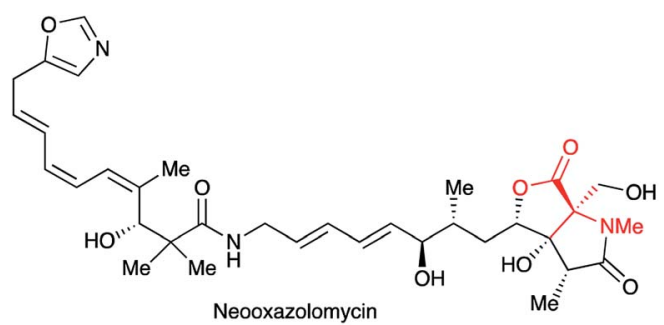

Fig. 1 Bioactive compounds possessing a quaternary $\alpha$-amino acid structure. 


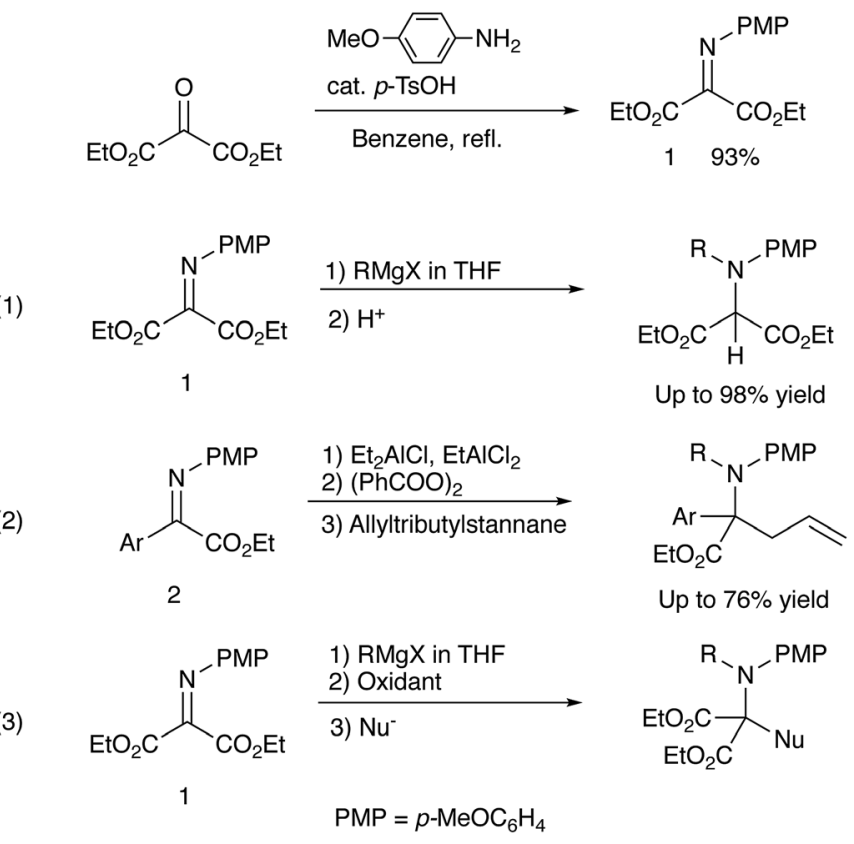

Scheme 1 Previous ${ }^{9 a, b}$ and present works.

We have now found that oxidation of the halomagnesium enolate derived from $N$-alkylation of the iminomalonate 1 with an appropriate oxidation reagent followed by $C$-nucleophilic addition leads to the formation of $N, C$-double addition products, quaternary $\alpha$-amino diesters in good yields (eqn (3), Scheme 1).

\section{Results and discussion}

\section{1 $N$-Methylation/C-cyanation reactions}

Our previous study leads to the $N$-ethylation/oxidation/Ccyanation reaction, which involves the formation of an intermediary iminium salt, responsible for the second nucleophilic addition. In the present examination, we carried out the double addition reaction as in the case with the previous one. ${ }^{9 b}$ Initially, methylation with methylmagnesium bromide, oxidation, and cyanation with TMSCN were examined regarding the oxidation reagent, and Table 1 summarizes the results.

As can be seen from Table 1, benzoyl peroxide (BPO) that was effective in the previous cyanation of $\alpha$-iminoesters did not work, ${ }^{9 b}$ whereas with $N$-chlorosuccinimide (NCS) or $N$-bromosuccinimide (NBS) the desired double addition product 3 was obtained, albeit in low yields. The low yield is presumably due to the instability of the intermediary iminium salt, and therefore, the oxidation in the presence of TMSCN was next examined. Table 2 summarizes the results.

As expected the reaction proceeded relatively well and the desired product 3 was formed in 56\% yield after $10 \mathrm{~min}$ (entry 1). Further optimization was carried out with respect to the reaction time; a prolonged reaction time of $4 \mathrm{~h}$ increased the product yield up to $64 \%$ (entry 2 ). We next
Table 1 Comparison of the oxidation reagents

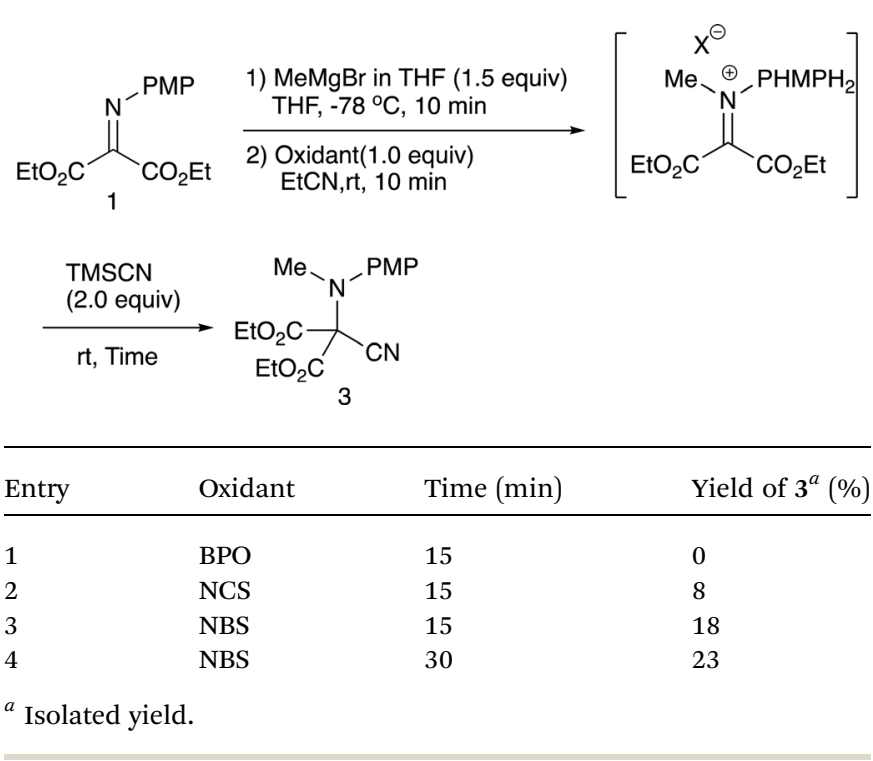

Table 2 Optimization of the reaction time

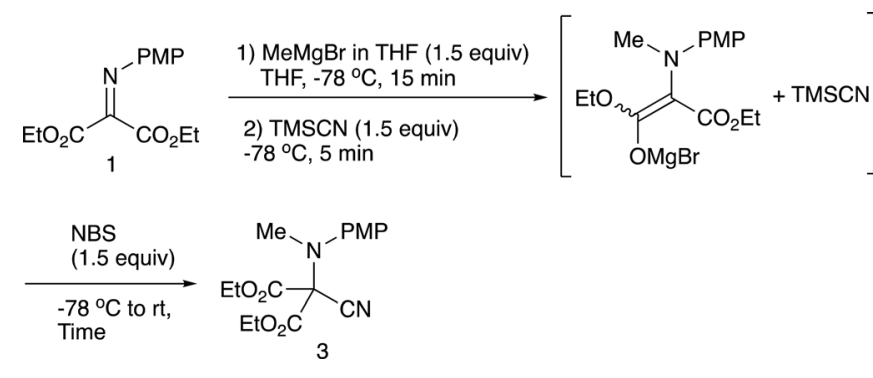

\begin{tabular}{lll}
\hline Entry & Time (min) & Yield of $3^{a}(\%)$ \\
\hline 1 & 10 & 56 \\
2 & 240 & 64 \\
3 & 10 & 56 \\
${ }^{a}$ Isolated yield. & &
\end{tabular}

examined the allylation reaction that would involve a stronger $\mathrm{C}-\mathrm{C}$ bond formation, and Table 3 summarizes the results.

\section{$2.2 N$-Methylation/ $C$-allylation reactions}

Although we initially examined the use of allyltrimethylsilane, allylmagnesium chloride, and ketene silyl acetals, these nucleophiles gave the addition products in only low yields (less than 20\%). Among the nucleophiles examined, teteraallylstannane effected the desired double addition reaction most efficiently. Treatment of the iminomalonate 1 with methylmagnesium bromide (1.5 equiv.) at $-78{ }^{\circ} \mathrm{C}$ followed by oxidation with NBS (1.5 equiv.) and allylation with tetrallylstannane (1.0 equiv.) gave the desired 


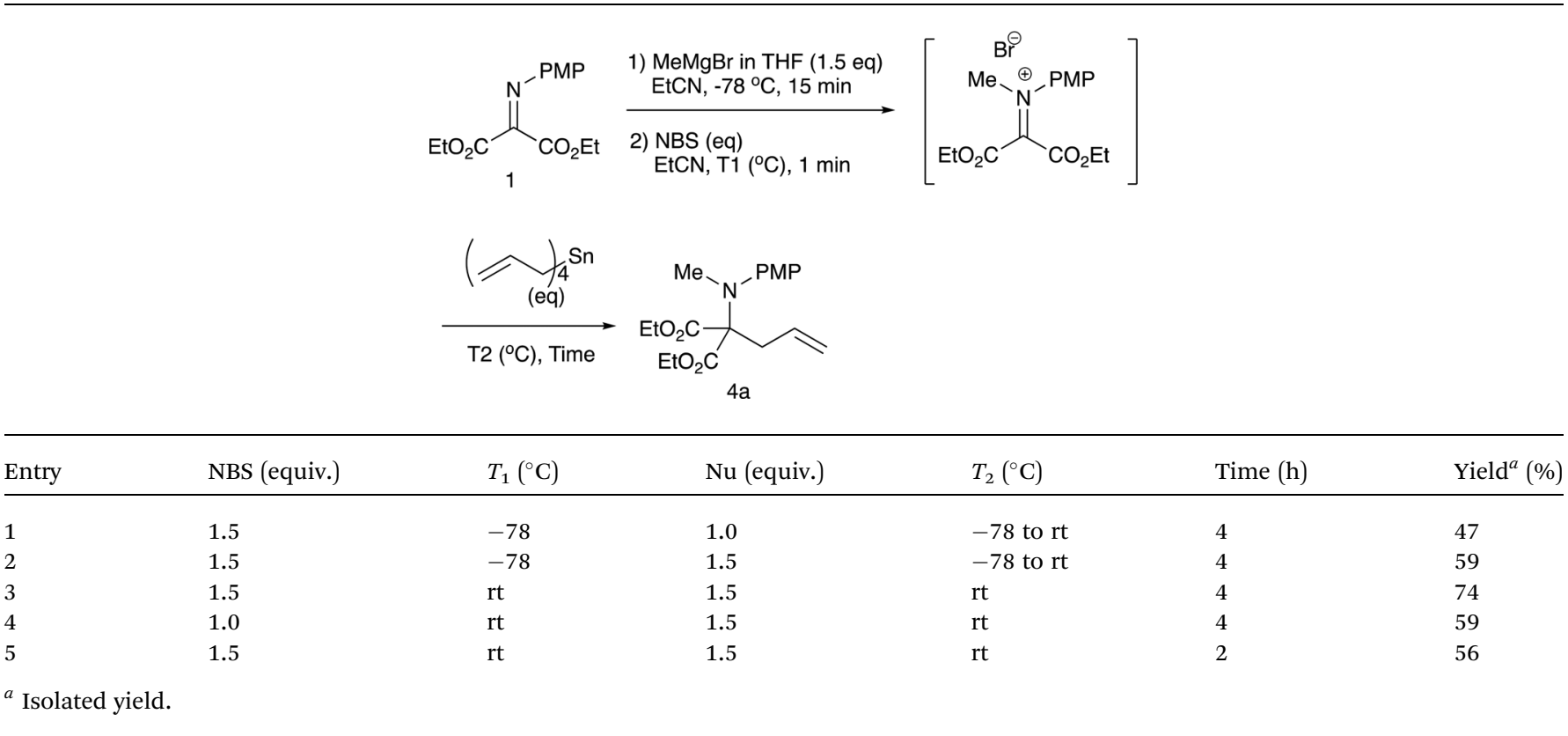

double addition product $4 \mathrm{a}$ in $47 \%$ yield (entry 1). Further examination into the reactions led to the optimum conditions. Use of NBS (1.5 equiv.) and tetrallylstannane (1.5 equiv.) at room temperature afforded the desired product $\mathbf{4 a}$ in $74 \%$ yield (entry 3 ). Under the optimized conditions, various Grignard reagents underwent double addition reactions to give good to high yields of products $\mathbf{4}$, and Table 4 summarizes the results.

Table 4 Use of various Grignard reagents
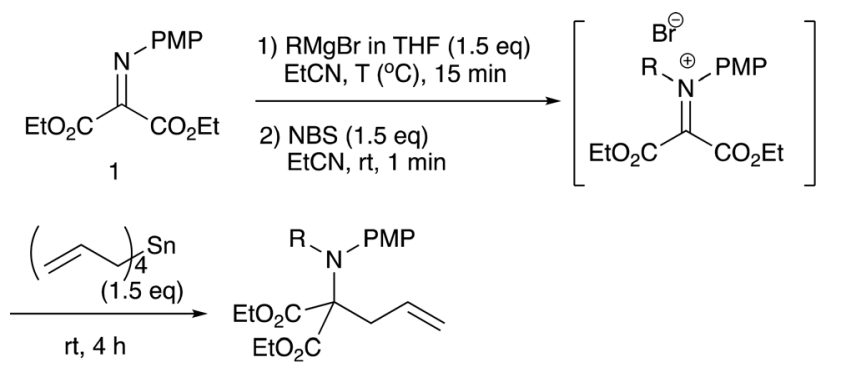

$4 a$ to $4 f$

\begin{tabular}{llll}
\hline Entry & $\mathrm{RMgX}$ & $T\left({ }^{\circ} \mathrm{C}\right)$ & 4: Yield $^{a}(\%)$ \\
\hline 1 & $\mathrm{MeMgBr}$ & -78 & 4a: 74 \\
2 & EtMgBr & -78 & 4b: 68 \\
3 & $n \mathrm{PrMgBr}$ & -78 & 4c: 79 \\
4 & $n \mathrm{BuMgBr}$ & -78 & 4d: 72 \\
5 & $\mathrm{iPrMgBr}$ & -90 & $\mathbf{4 e : ~} 40$ \\
6 & $t \mathrm{BuMgBr}$ & -90 & $\mathbf{4 f :}$ Trace \\
7 & $\mathrm{PhMgBr}$ & -90 & $\mathbf{4 g :} 0$
\end{tabular}

${ }^{a}$ Isolated yield.
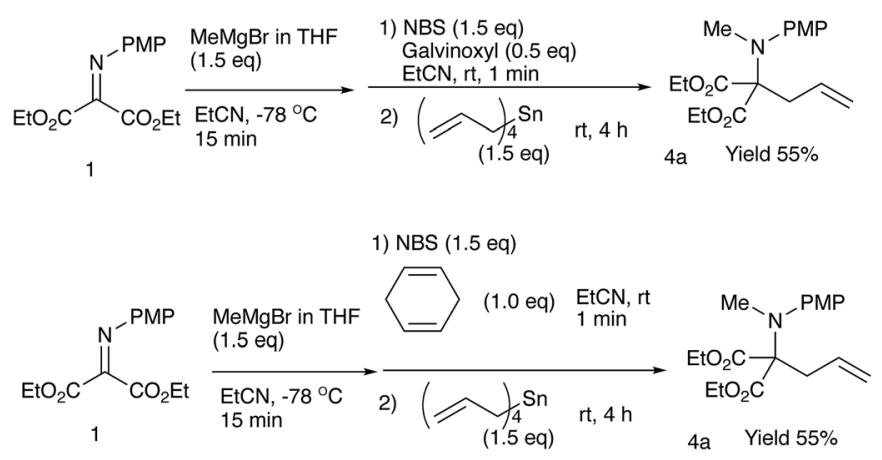

Scheme 2 Reactions in the presence of a radical scavenger or a quencher.
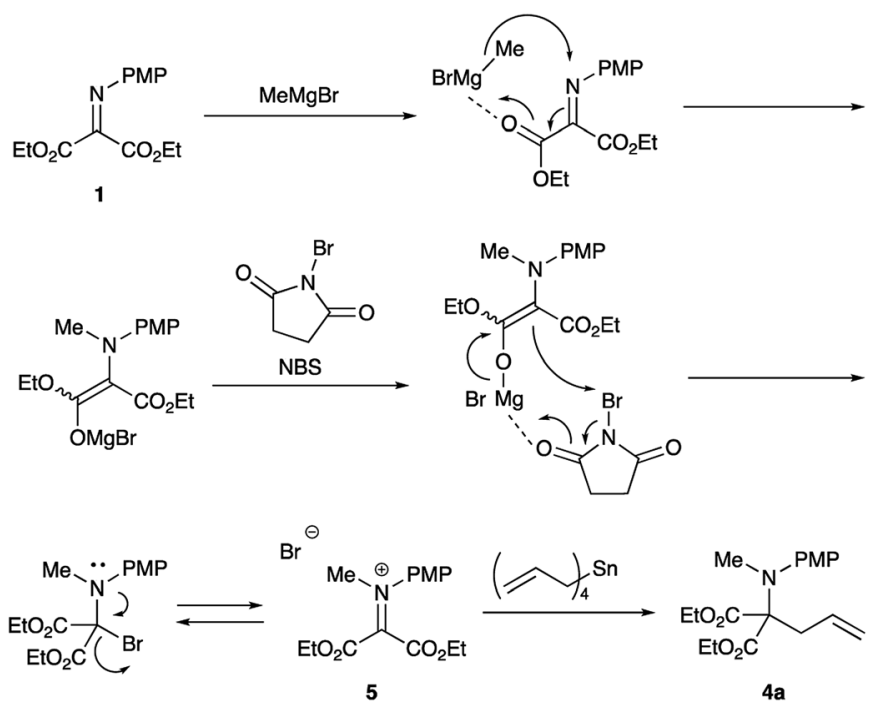

Scheme 3 Proposed reaction mechanism. 


\section{$2.3 \quad N$-Alkylation/C-allylation reactions}

As shown in Table 4, methyl, ethyl, npropyl, and $n$ butyl Grignard reagents underwent $N$-addition reaction rapidly and cleanly, and the subsequent oxidation and allylation also proceeded well to give $N$-alkylation $C$-allylation products $4 \mathbf{a}-\mathbf{d}$ in good yields (entries 1 to 4 ), whereas sterically bulky iso-propyl and tert-butyl counterparts effected the first addition reaction sluggishly to give the desired products $\mathbf{4 e -}$ f in moderate to low yields (entries 5 and 6). The present double addition reaction has a limitation; aromatic Grignard reagents did not effect the overall tandem addition, although the first umpolung addition to the nitrogen actually gave the single addition product in $59 \%$ yield (entry 7). ${ }^{9 a}$ To examine the reaction pathways, these control experiments were carried out (Scheme 2).

\subsection{Control experiments and a proposed reaction mechanism}

The reaction was carried out in the presence of a radical scavenger or a quencher. The yields of the desired product 4a did not noticeably decrease. These results indicate that no radical pathway would be involved in the present reaction. On the basis of these results and our previous investigations ${ }^{9 b}$ the following pathways are proposed (Scheme 3).

First, Grignard reagent attacks at the nitrogen atom to form the halomagnesium enolate, which is oxidized with NBS to form the iminium salt $\mathbf{5}$. This iminium salt $\mathbf{5}$ is attacked by tetraallylstannane to give the desired double addition product $\mathbf{4 a}$.

\subsection{Desymmetrization of the products}

For further use of products 4 , we carried out desymmetrization reactions of the aminodiesters 4 . The initial examination was carried out using biocatalysts such as lipases for the asymmetric hydrolysis of the ester moiety. ${ }^{10}$ However, none of the satisfactory results was obtained. We next examined chemical transformations via asymmetric acylation of the diol 6a derived from the diester $4 \mathbf{a}$ catalyzed by $\mathrm{Cu}$-Bnbox system, which finally worked well to give chiral products 7 with good enantio-purities. ${ }^{11}$ The reduction of the diester $4 \mathbf{a}$ was carried out using $\mathrm{LiAlH}_{4}$ to give the diol $\mathbf{6 a}$ in $81 \%$ yield (Scheme 4 ). Table 5 summarizes the results of the subsequent desymmetrization.

The desymmetrization reaction was carried out with aryl isocyanate in the presence of a catalytic amount of copper(II) triflate and a ligand in THF. Among the ligands examined, the use of Bnbox recorded the best result of $64 \%$ ee (entry 1 ), while tridentate ligands, pybox derivatives, did not work well in the present system (entries 5 and 6). An increase in the amount of both the ligand and $\mathrm{Cu}$ (II) to $50 \mathrm{~mol} \%$ gave a slight increase in the enantiopurity of $66 \%$ (entry 2). Further increase in the ees would be possible by changing ArNCO derivatives, and the results will be reported elsewhere.

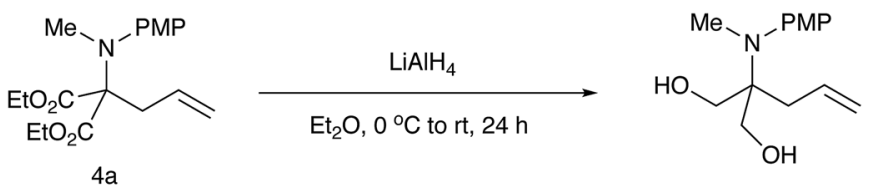

6 a Yield $81 \%$

Scheme 4 Reduction of the diester $4 a$

Table 5 Comparison of the chiral ligands
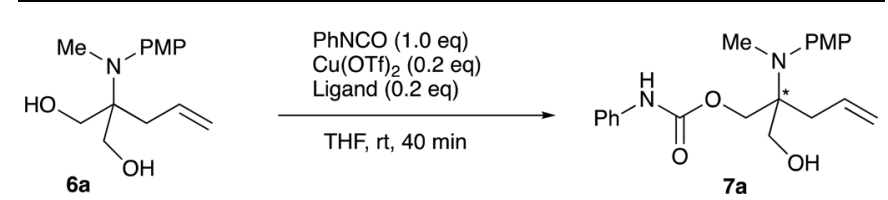

\begin{tabular}{llll}
\hline Entry & Ligand & Yield $^{a}(\%)$ & $\operatorname{Ee}^{b}(\%)$ \\
\hline 1 & Bnbox & 60 & 64 \\
2 & Bnbox & 67 & 66 \\
3 & Phbox & 82 & 42 \\
4 & iPrbox & 92 & 58 \\
5 & Ph-pybox & 67 & 3 \\
6 & iPr-pybox & 81 & 1
\end{tabular}

${ }^{a}$ Isolated yield. ${ }^{b}$ Determined by chiral HPLC analysis. ${ }^{c} \mathrm{Cu}(\mathrm{OTf})_{2}(0.5$ equiv.) and Bnbox (0.5 equiv.) were used.

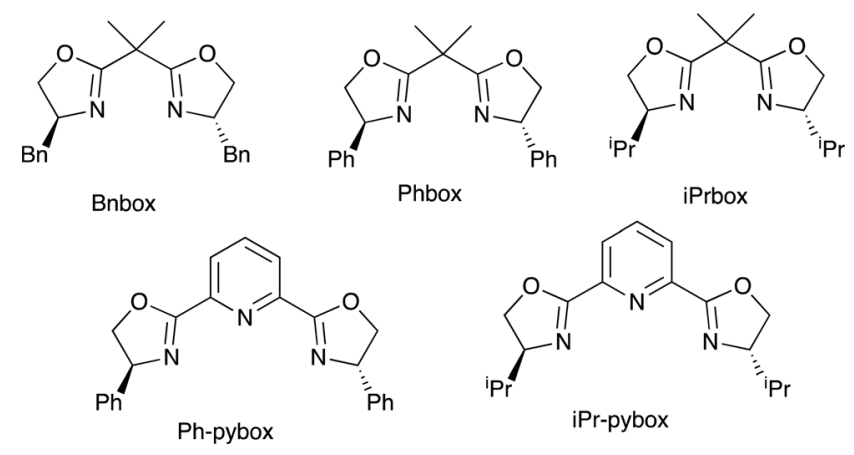

\section{Conclusions}

A double nucleophilic addition to iminomalonate was developed using the tandem $N$-alkylation/oxidation/allylation reaction of diethyl 2-[N-(p-methoxyphenyl)imino]malonate with Grignard reagent/NBS/tetraallylstannane in good to high yields. We also found that the desymmetrization of a diol derivative of the above products with $\mathrm{ArNCO} / \mathrm{Cu}(\mathrm{II})-\mathrm{Bnbox}$ gave a monocarbamate in good enantiomeric excess.

\section{Experimental}

\subsection{General aspects}

${ }^{1} \mathrm{H}$ NMR and ${ }^{13} \mathrm{C}$ NMR spectra were recorded with a JEOL ECX$400 \mathrm{P}$, or a JEOL A-500 spectrometer using tetramethylsilane as an internal standard. Mass spectra were recorded on a JEOL MS- 
700D spectrometer. High performance liquid chromatography was carried out using these apparatuses; HITACHI Pump L2130, Column Oven L-2300, and UV Detector L-2400. Propionitrile (EtCN) was distilled from phosphorus pentaoxide and then from calcium hydride, and stored over Molecular Sieves 4A. Tetrahydrofuran (THF) and diethyl ether $\left(\mathrm{Et}_{2} \mathrm{O}\right)$ were purified with a Glass Contour Organic Solvent Purification System of Nikko Hansen \& Co., Ltd. Benzene was dried over calcium chloride, distilled, and stored over Molecular Sieves 4A. Purification of products was performed by column chromatography on silica gel (Kanto Silica Gel 60N) and/or preparative TLC on silica gel (Merck Kiesel Gel GF254 or Wako Gel B-5F).

\subsection{Synthesis of diethyl 2-[ $N$-(4-methoxyphenyl)imino]- malonate (1)}

This compound $\mathbf{1}$ was prepared according to the published procedure. ${ }^{9 a, 12-14}$

\subsection{Synthesis of diethyl 2-[N-(4-methoxyphenyl)- $N$ - methylamino]-2-cyanomalonate (3)}

Method A. In a $30 \mathrm{~mL}$ two-necked round-bottomed flask equipped with a magnetic stirring bar, a rubber septum, and an argon balloon was placed diethyl 2-[N-(p-methoxyphenyl)imino] malonate (41.9 mg, $0.15 \mathrm{mmol})$ in THF $(1.0 \mathrm{~mL})$ at $-78^{\circ} \mathrm{C}$. To it was added MeMgBr $(0.21 \mathrm{~mL}, 0.23 \mathrm{mmol}, 1.12 \mathrm{M}$ THF). After the mixture was stirred for $10 \mathrm{~min}$ at room temperature, to it were added NBS (36.3 mg, $0.15 \mathrm{mmol})$ and EtCN $(1.0 \mathrm{~mL})$, and the reaction mixture was stirred for $15 \mathrm{~min}$ at room temperature. Then, TMSCN $(0.037 \mathrm{~mL}, 0.30 \mathrm{mmol})$ was added and the mixture was stirred at room temperature for $30 \mathrm{~min}$. The reaction was quenched with sat aq $\mathrm{NaHCO}_{3}(20.0 \mathrm{~mL})$, and the whole mixture was extracted with ethyl acetate $(10 \mathrm{~mL} \times 2)$. The combined extracts were washed with brine $(10 \mathrm{~mL})$, dried over anhydrous $\mathrm{Na}_{2} \mathrm{SO}_{4}$, and concentrated in vacuo. The crude product was purified on silica gel TLC (ethyl acetate $/ n$ hexane $=1 / 4)$ to give the title compound $3(10.9 \mathrm{mg}, 23 \%)$ as a yellow oil. $R_{\mathrm{f}}=0.5$ (ethyl acetate/nhexane $\left.=1 / 4\right) ;{ }^{1} \mathrm{H}$ NMR $(400$ $\left.\mathrm{MHz}, \mathrm{CDCl}_{3}\right) \delta: 1.21(\mathrm{t}, J=7.1 \mathrm{~Hz}, 6 \mathrm{H}), 2.94(\mathrm{~s}, 3 \mathrm{H}), 3.78(\mathrm{~s}, 3 \mathrm{H})$, 4.19-4.27 (m, 4H), 6.80-6.84 (m, 2H), 7.30-7.34 (m, 2H); ${ }^{13} \mathrm{C}$ NMR $\left(100 \mathrm{MHz}, \mathrm{CDCl}_{3}\right) \delta: 13.7,41.5,55.4,64.1,74.9,113.5,114.2,127.1$, 140.5, 158.1, 161.9; HRMS (EI) calcd for $\mathrm{C}_{16} \mathrm{H}_{20} \mathrm{~N}_{2} \mathrm{O}_{5}\left(\mathrm{M}-\mathrm{C}_{3} \mathrm{H}_{5} \mathrm{O}_{2}\right)^{+}$ 320.1372, found 320.1363 .

Method B. In a $30 \mathrm{~mL}$ two-necked round-bottomed flask equipped with a magnetic stirring bar, a rubber septum, and an argon balloon was placed diethyl 2-[N-(p-methoxyphenyl)imino] malonate ( $41.9 \mathrm{mg}, 0.15 \mathrm{mmol})$ in THF $(1.0 \mathrm{~mL})$ at $-78^{\circ} \mathrm{C}$. To it was added $\mathrm{MeMgBr}(0.20 \mathrm{~mL}, 0.23 \mathrm{mmol}, 1.12 \mathrm{M}$ THF$)$. After the mixture was stirred for $15 \mathrm{~min}$ at $-78{ }^{\circ} \mathrm{C}$, TMSCN $(28.0 \mu \mathrm{L}, 0.23$ mmol) was added at that temperature and the mixture was stirred for $5 \mathrm{~min}$. Then, NBS (40.0 mg, $0.23 \mathrm{mmol})$ and EtCN $(1.0 \mathrm{~mL})$ were added, and the reaction mixture was stirred for $4 \mathrm{~h}$ at room temperature. The reaction was quenched with sat aq $\mathrm{NaHCO}_{3}(20.0$ $\mathrm{mL})$, and the whole mixture was extracted with ethyl acetate $(10 \mathrm{~mL}$ $\times 2)$. The combined extracts were washed with brine $(10 \mathrm{~mL})$, dried over anhydrous $\mathrm{Na}_{2} \mathrm{SO}_{4}$, and concentrated in vacuo. The crude product was purified on silica gel TLC (ethyl acetate $/$ nhexane $=1 / 4$ ) to give the title compound $3(30.6 \mathrm{mg}, 64 \%)$ as a yellow oil.

\subsection{Synthesis of diethyl 2-[ $\mathrm{N}$-(4-methoxyphenyl)- $\mathrm{N}$ -} methylamino]-2-allylmalonate (4a)

In a $30 \mathrm{~mL}$ two-necked round-bottomed flask equipped with a magnetic stirring bar, a rubber septum, and an argon balloon was placed diethyl 2-[N-(p-methoxyphenyl)imino]malonate $(41.9 \mathrm{mg}$, $0.15 \mathrm{mmol})$ in THF $(1.0 \mathrm{~mL})$ at $-78{ }^{\circ} \mathrm{C}$. To it was added $\mathrm{MeMgBr}$ (0.20 mL, $0.23 \mathrm{mmol}, 0.99 \mathrm{M} \mathrm{THF})$. After the mixture was stirred for $15 \mathrm{~min}$ at room temperature, to it were added NBS $(40.0 \mathrm{mg}, 0.23$ $\mathrm{mmol}$ ) and EtCN (1.0 mL), and the reaction mixture was stirred for $1 \mathrm{~min}$ at room temperature. Then, tetraallylstannane $(0.054 \mathrm{~mL}$, $0.23 \mathrm{mmol}$ ) was added and the mixture was stirred at room temperature for $4 \mathrm{~h}$. The reaction was quenched with sat aq $\mathrm{NaHCO}_{3}(20.0 \mathrm{~mL})$, and the whole mixture was extracted with ethyl acetate $(10 \mathrm{~mL} \times 2)$. The combined extracts were washed with brine $(10 \mathrm{~mL})$, dried over anhydrous $\mathrm{Na}_{2} \mathrm{SO}_{4}$, and concentrated in vacuo. The crude product was purified on silica gel TLC (ethyl acetate/ $n$ hexane $=1 / 4)$ to give the title compound 4 a $(35.4 \mathrm{mg}, 74 \%)$ as a colorless oil. $R_{\mathrm{f}}=0.5$ (ethyl acetate $/ n$ hexane $\left.=1 / 4\right) ;{ }^{1} \mathrm{H}$ NMR (400 $\left.\mathrm{MHz} \mathrm{CDCl}_{3}\right) \delta: 1.29(\mathrm{t}, J=7.1 \mathrm{~Hz}, 6 \mathrm{H}), 2.60(\mathrm{~d}, J=6.9,2 \mathrm{H}), 2.95(\mathrm{~s}$, $3 \mathrm{H}), 3.77(\mathrm{~s}, 3 \mathrm{H}), 4.26$ (q, $J=7.0), 4.93-5.01(\mathrm{~m}, 2 \mathrm{H}), 5.79-5.89(\mathrm{~m}$, 1H), 6.77-6.81 (m, 2H), 7.08-7.12 (m, 2H); ${ }^{13} \mathrm{C}$ NMR (100 MHz, $\left.\mathrm{CDCl}_{3}\right) \delta: 14.2,40.1,41.9,55.3,61.2,74.6,113.9,118.0,128.2,133.0$, 141.8, 156.9, 169.8; HRMS (EI) calcd for $\mathrm{C}_{18} \mathrm{H}_{25} \mathrm{NO}_{5}\left(\mathrm{M}-\mathrm{C}_{3} \mathrm{H}_{5} \mathrm{O}_{2}\right)^{+}$ 355.1733 , found 355.1723 .

\subsection{Synthesis of diethyl 2-[N-(4-methoxyphenyl)- $N$ - ethylamino]-2-allylmalonate $(4 \mathrm{~b})$}

In a $30 \mathrm{~mL}$ two-necked round-bottomed flask equipped with a magnetic stirring bar, a rubber septum, and an argon balloon was placed diethyl 2-[N-(p-methoxyphenyl)imino]malonate $(41.9 \mathrm{mg}$, $0.15 \mathrm{mmol})$ in THF $(1.0 \mathrm{~mL})$ at $-78{ }^{\circ} \mathrm{C}$. To it was added EtMgBr (0.25 mL, $0.23 \mathrm{mmol}, 0.91 \mathrm{M} \mathrm{THF}$ ). After the mixture was stirred for $15 \mathrm{~min}$ at room temperature, to it were added NBS $(26.7 \mathrm{mg}, 0.15$ $\mathrm{mmol}$ ) and $\mathrm{EtCN}(1.0 \mathrm{~mL})$, and the reaction mixture was stirred for $1 \mathrm{~min}$ at room temperature. Then, tetraallylstannane $(0.054 \mathrm{~mL}$, $0.23 \mathrm{mmol}$ ) was added and the mixture was stirred at room temperature for $4 \mathrm{~h}$. The reaction was quenched with sat aq $\mathrm{NaHCO}_{3}(20.0 \mathrm{~mL})$, and the whole mixture was extracted with ethyl acetate $(10 \mathrm{~mL} \times 2)$. The combined extracts were washed with brine $(10 \mathrm{~mL})$, dried over anhydrous $\mathrm{Na}_{2} \mathrm{SO}_{4}$, and concentrated in vacuo. The crude product was purified on silica gel TLC (ethyl acetate/ $n$ hexane $=1 / 4)$ to give the title compound $4 \mathbf{b}(35.6 \mathrm{mg}, 68 \%)$ as a colorless oil. $R_{\mathrm{f}}=0.5$ (ethyl acetate/nhexane $=1 / 6$, developed twice); ${ }^{1} \mathrm{H}$ NMR $\left(400 \mathrm{MHz}, \mathrm{CDCl}_{3}\right) \delta: 0.90(\mathrm{t}, J=7.1 \mathrm{~Hz}, 3 \mathrm{H}), 1.30(\mathrm{t}, J$ $=7.1 \mathrm{~Hz}, 6 \mathrm{H}), 2.44-2.46(\mathrm{~m}, 2 \mathrm{H}), 3.17(\mathrm{q}, J=6.9 \mathrm{~Hz}, 2 \mathrm{H}), 3.78(\mathrm{~s}$, $3 \mathrm{H}), 4.25$ (q, $J=7.2 \mathrm{~Hz}, 4 \mathrm{H}), 4.91-4.99(\mathrm{~m}, 2 \mathrm{H}), 5.78-5.89(\mathrm{~m}, 1 \mathrm{H})$, 6.78-6.82 (m, 2H), 7.08-7.12 (m, 2H); $\left.{ }^{13} \mathrm{C} \mathrm{NMR} \mathrm{(100} \mathrm{MHz,} \mathrm{CDCl}_{3}\right) \delta$ : 14.2, 14.9, 40.4, 48.4, 55.3, 61.1, 75.6, 113.8, 117.7, 131.2, 133.4, 138.4, 157.8, 170.3; HRMS (EI) calcd for $\mathrm{C}_{19} \mathrm{H}_{27} \mathrm{NO}_{5}\left(\mathrm{M}-\mathrm{C}_{3} \mathrm{H}_{5} \mathrm{O}_{2}\right)^{+}$ 349.1889 , found 349.1892 .

\subsection{Synthesis of diethyl 2-[N-(4-methoxyphenyl)- $N$ - propylamino]-2-allylmalonate $(4 \mathrm{c})$}

In a $30 \mathrm{~mL}$ two-necked round-bottomed flask equipped with a magnetic stirring bar, a rubber septum, and an argon balloon was 
placed diethyl 2-[N-(p-methoxyphenyl)imino]malonate $(41.9 \mathrm{mg}$, $0.15 \mathrm{mmol})$ in THF $(1.0 \mathrm{~mL})$ at $-78^{\circ} \mathrm{C}$. To it was added $n \mathrm{PrMgBr}$ (0.24 mL, $0.23 \mathrm{mmol}, 0.93 \mathrm{M} \mathrm{THF})$. After the mixture was stirred for $15 \mathrm{~min}$ at room temperature, to it were added NBS (26.7 mg, 0.15 $\mathrm{mmol}$ ) and EtCN $(1.0 \mathrm{~mL})$, and the reaction mixture was stirred for $1 \mathrm{~min}$ at room temperature. Then, tetraallylstannane $(0.054 \mathrm{~mL}$, $0.23 \mathrm{mmol}$ ) was added and the mixture was stirred at room temperature for $4 \mathrm{~h}$. The reaction was quenched with sat aq $\mathrm{NaHCO}_{3}(20.0 \mathrm{~mL})$, and the whole mixture was extracted with ethyl acetate $(10 \mathrm{~mL} \times 2)$. The combined extracts were washed with brine $(10 \mathrm{~mL})$, dried over anhydrous $\mathrm{Na}_{2} \mathrm{SO}_{4}$, and concentrated in vacuo. The crude product was purified on silica gel TLC (ethyl acetate/ $n$ hexane $=1 / 4)$ to give the title compound $4 \mathrm{c}(43.3 \mathrm{mg}, 79 \%)$ as a yellow oil. $R_{\mathrm{f}}=0.5$ (ethyl acetate $/ n$ hexane $\left.=1 / 4\right) ;{ }^{1} \mathrm{H}$ NMR $(400$ $\left.\mathrm{MHz}, \mathrm{CDCl}_{3}\right) \delta: 0.82(\mathrm{t}, J=18.3 \mathrm{~Hz}, 3 \mathrm{H}), 1.28(\mathrm{~m}, 8 \mathrm{H}), 2.44(\mathrm{~d}, J=$ $6.9 \mathrm{~Hz}, 2 \mathrm{H}), 3.08(\mathrm{t}, J=7.4 \mathrm{~Hz}, 2 \mathrm{H}), 3.78(\mathrm{~s}, 2 \mathrm{H}), 4.25(\mathrm{q}, J=6.9 \mathrm{~Hz}$, $4 \mathrm{H}), 4.92-4.98(\mathrm{~m}, 2 \mathrm{H}), 5.77-5.88(\mathrm{~m}, 1 \mathrm{H}), 6.78-6.82(\mathrm{~m}, 2 \mathrm{H}), 7.09-$ $7.13(\mathrm{~m}, 2 \mathrm{H}) ;{ }^{13} \mathrm{C}$ NMR $\left(100 \mathrm{MHz}, \mathrm{CDCl}_{3}\right) \delta: 11.2,14.2,22.3,40.5$, 55.3, 55.7, 61.0, 75.6, 113.7, 117.7, 130.9, 133.4, 138.7, 157.7, 170.2; HRMS (EI) calcd for $\mathrm{C}_{20} \mathrm{H}_{29} \mathrm{NO}_{5}\left(\mathrm{M}-\mathrm{C}_{3} \mathrm{H}_{5} \mathrm{O}_{2}\right)^{+} 363.2046$, found 363.2038.

\subsection{Synthesis of diethyl 2-[N-(4-methoxyphenyl)- $N$ - butylamino]-2-allylmalonate $(4 \mathrm{~d})$}

In a $30 \mathrm{~mL}$ two-necked round-bottomed flask equipped with a magnetic stirring bar, a rubber septum, and an argon balloon was placed diethyl 2-[N-(p-methoxyphenyl)imino]malonate (41.9 mg, $0.15 \mathrm{mmol})$ in THF $(1.0 \mathrm{~mL})$ at $-78^{\circ} \mathrm{C}$. To it was added $n$ BuMgBr $(0.20 \mathrm{~mL}, 0.23 \mathrm{mmol}, 1.1 \mathrm{M} \mathrm{THF})$. After the mixture was stirred for $15 \mathrm{~min}$ at room temperature, to it were added NBS $(26.7 \mathrm{mg}, 0.15 \mathrm{mmol})$ and EtCN $(1.0 \mathrm{~mL})$, and the reaction mixture was stirred for $1 \mathrm{~min}$ at room temperature. Then, tetraallylstannane $(0.054 \mathrm{~mL}, 0.23 \mathrm{mmol})$ was added and the mixture was stirred at room temperature for $4 \mathrm{~h}$. The reaction was quenched with sat aq $\mathrm{NaHCO}_{3}(20.0 \mathrm{~mL})$, and the whole mixture was extracted with ethyl acetate $(10 \mathrm{~mL} \times 2)$. The combined extracts were washed with brine $(10 \mathrm{~mL})$, dried over anhydrous $\mathrm{Na}_{2} \mathrm{SO}_{4}$, and concentrated in vacuo. The crude product was purified on silica gel TLC (ethyl acetate/nhexane $=$ $1 / 4)$ to give the title compound $\mathbf{4 d}(40.7 \mathrm{mg}, 72 \%)$ as a yellow oil. $R_{\mathrm{f}}=0.5$ (ethyl acetate $/ n$ hexane $\left.=1 / 4\right) ;{ }^{1} \mathrm{H}$ NMR $(400 \mathrm{MHz}$, $\left.\mathrm{CDCl}_{3}\right) \delta: 0.81(\mathrm{t}, J=6.8 \mathrm{~Hz}, 3 \mathrm{H}), 1.24-1.32(\mathrm{~m}, 10 \mathrm{H}), 2.44(\mathrm{~d}, J=$ $6.9 \mathrm{~Hz}, 2 \mathrm{H}), 3.10(\mathrm{t}, J=6.8 \mathrm{~Hz}, 2 \mathrm{H}), 3.79(\mathrm{~s}, 3 \mathrm{H}), 4.25(\mathrm{q}, J=$ $7.1 \mathrm{~Hz}, 4 \mathrm{H}), 4.92-4.98(\mathrm{~m}, 2 \mathrm{H}), 5.78-5.88(\mathrm{~m}, 1 \mathrm{H}), 6.79-6.82(\mathrm{~m}$, $2 \mathrm{H}), 7.08-7.12(\mathrm{~m}, 2 \mathrm{H}):{ }^{13} \mathrm{C} \mathrm{NMR}\left(100 \mathrm{MHz}, \mathrm{CDCl}_{3}\right) \delta: 14.1,14.2$, 20.0, 31.5, 40.5, 53.8, 55.3, 61.0, 75.6, 113.7, 117.8, 130.9, 133.3, 138.7, 157.7, 170.2; HRMS (EI) calcd for $\mathrm{C}_{21} \mathrm{H}_{31} \mathrm{NO}_{5}(\mathrm{M}-$ $\left.\mathrm{C}_{3} \mathrm{H}_{5} \mathrm{O}_{2}\right)^{+}$377.2202, found 377.2201.

\subsection{Synthesis of diethyl 2-[N-(4-methoxyphenyl)- $N$-(2-propyl) amino]-2-allylmalonate (4e)}

In a $30 \mathrm{~mL}$ two-necked round-bottomed flask equipped with a magnetic stirring bar, a rubber septum, and an argon balloon was placed diethyl 2-[N-(p-methoxyphenyl)imino]malonate (41.9 mg, $0.15 \mathrm{mmol})$ in THF $(1.0 \mathrm{~mL})$ at $-90^{\circ} \mathrm{C}$. To it was added iPrMgBr $(0.27 \mathrm{~mL}, 0.23 \mathrm{mmol}, 0.85 \mathrm{M} \mathrm{THF})$. After the mixture was stirred for $15 \mathrm{~min}$ at room temperature, to it were added NBS $(26.7 \mathrm{mg}, 0.15 \mathrm{mmol})$ and EtCN $(1.0 \mathrm{~mL})$, and the reaction mixture was stirred for $1 \mathrm{~min}$ at room temperature. Then, tetraallylstannane $(0.054 \mathrm{~mL}, 0.23 \mathrm{mmol})$ was added and the mixture was stirred at room temperature for $4 \mathrm{~h}$. The reaction was quenched with sat aq $\mathrm{NaHCO}_{3}(20.0 \mathrm{~mL})$, and the whole mixture was extracted with ethyl acetate $(10 \mathrm{~mL} \times 2)$. The combined extracts were washed with brine $(10 \mathrm{~mL})$, dried over anhydrous $\mathrm{Na}_{2} \mathrm{SO}_{4}$, and concentrated in vacuo. The crude product was purified on silica gel TLC (ethyl acetate/nhexane $=$ $1 / 4)$ to give the title compound $4 \mathbf{e}(22.1 \mathrm{mg}, 40 \%)$ as a yellow oil. $R_{\mathrm{f}}=0.5$ (ethyl acetate/nhexane $\left.=1 / 4\right) ;{ }^{1} \mathrm{H}$ NMR $(400 \mathrm{MHz}$, $\left.\mathrm{CDCl}_{3}\right) \delta: 0.97(\mathrm{~d}, J=6.6 \mathrm{~Hz}, 6 \mathrm{H}), 1.31(\mathrm{t}, J=7.1 \mathrm{~Hz}, 6 \mathrm{H}), 2.50(\mathrm{~d}$, $J=7.1 \mathrm{~Hz}, 2 \mathrm{H}), 3.60-3.67(\mathrm{~m}, 1 \mathrm{H}), 3.79(\mathrm{~s}, 3 \mathrm{H}), 4.19-4.32(\mathrm{~m}$, $4 \mathrm{H})$, 4.76-4.92 (m, 2H), 5.61-5.71 (m.1H), 6.77-6.81 (m, 2H), 7.06-7.10 (m, 2H); ${ }^{13} \mathrm{C}$ NMR (100 MHz, $\left.\mathrm{CDCl}_{3}\right) \delta: 11.5,14.1,22.6$, 40.0, 51.5, 55.2, 61.14, 74.65, 113.0, 117.7, 133.1, 133.9, 157.5, 171.57; HRMS (EI) Calculated for $\mathrm{C}_{20} \mathrm{H}_{29} \mathrm{NO}_{5}\left(\mathrm{M}-\mathrm{C}_{3} \mathrm{H}_{5} \mathrm{O}_{2}\right)^{+}$ 363.2046, found 363.2043.

\subsection{Synthesis of diethyl 2-[N-(4-methoxyphenyl)- $N$ - methylamino]-2-allylmalonate $(4 a)$ in the presence of galvioxiyl}

In a $30 \mathrm{~mL}$ two-necked round-bottomed flask equipped with a magnetic stirring bar, a rubber septum, and an argon balloon was placed diethyl 2-[N-(p-methoxyphenyl)imino]malonate (41.9 mg, $0.15 \mathrm{mmol})$ in THF $(1.0 \mathrm{~mL})$ at $-78^{\circ} \mathrm{C}$. To it was added MeMgBr (0.20 mL, $0.23 \mathrm{mmol}, 0.99 \mathrm{M} \mathrm{THF})$. After the mixture was stirred for $15 \mathrm{~min}$ at room temperature, to it were added NBS (40.0 mg, $0.23 \mathrm{mmol}$ ), galvioxyl $(7.2 \mathrm{mg}, 0.23 \mathrm{mmol})$, and EtCN $(1.0 \mathrm{~mL})$, and the reaction mixture was stirred for $1 \mathrm{~min}$ at room temperature. Then, tetraallylstannane $(0.054 \mathrm{~mL}, 0.23$ $\mathrm{mmol}$ ) was added and the mixture was stirred at room temperature for $4 \mathrm{~h}$. The reaction was quenched with sat aq $\mathrm{NaHCO}_{3}(20.0 \mathrm{~mL})$, and the whole mixture was extracted with ethyl acetate $(10 \mathrm{~mL} \times 2)$. The combined extracts were washed with brine $(10 \mathrm{~mL})$, dried over anhydrous $\mathrm{Na}_{2} \mathrm{SO}_{4}$, and concentrated in vacuo. The crude product was purified on silica gel TLC (ethyl acetate/nhexane $=1 / 4$ ) to give the title compound 4a (26.3 mg, 55\%) as a colorless oil.

\subsection{Synthesis of diethyl 2-[N-(4-methoxyphenyl)- $N$ - methylamino]-2-allylmalonate $(4 a)$ in the presence of 1,4 - cyclohexadiene}

In a $30 \mathrm{~mL}$ two-necked round-bottomed flask equipped with a magnetic stirring bar, a rubber septum, and an argon balloon was placed diethyl 2-[N-(p-methoxyphenyl)imino]malonate (41.9 mg, $0.15 \mathrm{mmol})$ in THF $(1.0 \mathrm{~mL})$ at $-78^{\circ} \mathrm{C}$. To it was added MeMgBr (0.20 mL, $0.23 \mathrm{mmol}, 0.99 \mathrm{M} \mathrm{THF})$. After the mixture was stirred for $15 \mathrm{~min}$ at room temperature, to it were added NBS (40.0 mg, $0.23 \mathrm{mmol}$ ), 1,4-cyclohexadiene (80.13 mg, 0.075 $\mathrm{mmol})$, and EtCN $(1.0 \mathrm{~mL})$, and the reaction mixture was stirred for $1 \mathrm{~min}$ at room temperature. Then, tetraallylstannane $(0.054$ $\mathrm{mL}, 0.23 \mathrm{mmol}$ ) was added and the mixture was stirred at room temperature for $4 \mathrm{~h}$. The reaction was quenched with sat aq $\mathrm{NaHCO}_{3}(20.0 \mathrm{~mL})$, and the whole mixture was extracted with 
ethyl acetate $(10 \mathrm{~mL} \times 2)$. The combined extracts were washed with brine $(10 \mathrm{~mL})$, dried over anhydrous $\mathrm{Na}_{2} \mathrm{SO}_{4}$, and concentrated in vacuo. The crude product was purified on silica gel TLC (ethyl acetate/ $n$ hexane $=1 / 4$ ) to give the title compound 4a $(26.3 \mathrm{mg}, 55 \%)$ as a colorless oil.

\subsection{Synthesis of 2-[N-(4-methoxyphenyl)- $N$-methylamino]-2- allylpropan-1,3-diol (6a)}

In a $50 \mathrm{~mL}$ two-necked round-bottomed flask equipped with a magnetic stirring bar, an argon balloon, and a rubber septum was placed $\mathrm{LiAlH}_{4}(0.33 \mathrm{~g}, 8.7 \mathrm{mmol})$. To it was added a solution of diethyl 2-[N-(4-methoxyphenyl)- $N$-methylamino $]-2$ allylmalonate $(1.0 \mathrm{~g}, 3.1 \mathrm{mmol})$ in $\mathrm{Et}_{2} \mathrm{O}(30 \mathrm{~mL})$ at $0{ }^{\circ} \mathrm{C}$, and the whole mixture was stirred at room temperature for $16 \mathrm{~h}$. The reaction was quenched with sat aq $\mathrm{Na}_{2} \mathrm{SO}_{4}$, and the whole mixture was filtered through a pad of Celite. The filtrate was concentrated in vacuo to give a crude oil, which was purified by silica gel column chromatography (ethyl acetate/nhexane $=1 / 2$ ) to give the title compound $\mathbf{6 a}(0.64 \mathrm{~g}, 81 \%)$ as a colorless oil. $R_{\mathrm{f}}$ $=0.1$ (ethyl acetate $/ n$ hexane $=1 / 2) ;{ }^{1} \mathrm{H} \mathrm{NMR}\left(400 \mathrm{MHz}, \mathrm{CDCl}_{3}\right.$ ) $\delta: 2.25(\mathrm{~d}, J=7.3 \mathrm{~Hz}, 2 \mathrm{H}), 2.55(\mathrm{~s}, 2 \mathrm{H}), 2.82(\mathrm{~s}, 3 \mathrm{H}), 3.63(\mathrm{q}, J=$ 11.5, $8.4 \mathrm{~Hz}, 4 \mathrm{H}), 3.80(\mathrm{~s}, 3 \mathrm{H}), 5.05-5.12(\mathrm{~m}, 2 \mathrm{H}), 5.73-5.83(\mathrm{~m}$, $1 \mathrm{H}), 6.82-6.86(\mathrm{~m}, 2 \mathrm{H}), 7.21-7.25(\mathrm{~m}, 2 \mathrm{H}) ;{ }^{13} \mathrm{C}$ NMR $(100 \mathrm{MHz}$, $\left.\mathrm{CDCl}_{3}\right) \delta: 34.7,37.3,55.4,63.8,64.7,113.8,118.3,129.0,133.8$, 141.9, 157.1; HRMS (EI) calcd for $\mathrm{C}_{14} \mathrm{H}_{21} \mathrm{NO}_{3}\left(\mathrm{M}-\mathrm{C}_{3} \mathrm{H}_{5} \mathrm{O}_{2}\right)^{+}$ 251.1521, found 251.1524.

\subsection{Desymmetrization of 2-[N-(4-methoxyphenyl)- $N$ - methylamino]-2-allylpropan-1,3-diol}

In a $30 \mathrm{~mL}$ two-necked round-bottomed flask equipped with a magnetic stirring bar, a rubber septum, and an argon balloon were placed $\mathrm{Cu}(\mathrm{OTf})_{2}(10.9 \mathrm{mg}, 0.03 \mathrm{mmol})$ and Bnbox (10.9 mg, $0.03 \mathrm{mmol})$. To it were added a solution of 2-[N-(4-methoxyphenyl)- $N$-methylamino]-2-allylpropan-1,3-diol (37.7 mg, 0.15 $\mathrm{mmol})$ in THF $(1.5 \mathrm{~mL})$ and $\operatorname{PhNCO}(16.0 \mu \mathrm{L}, 0.15 \mathrm{mmol})$. After the mixture was stirred for $40 \mathrm{~min}$ at room temperature, it was quenched with $\mathrm{H}_{2} \mathrm{O}(20.0 \mathrm{~mL})$, and the whole mixture was extracted with ethyl acetate $(10 \mathrm{~mL} \times 2)$. The combined extracts were washed with brine $(10 \mathrm{~mL})$, dried over anhydrous $\mathrm{Na}_{2} \mathrm{SO}_{4}$, and concentrated in vacuo. The crude product was purified on silica gel TLC (ethyl acetate/nhexane $=1 / 2$ ) to give $2-[N-(4-$ methoxyphenyl)- $N$-methylamino]-2-allyl-3-

hydroxypropylphenylcarbamate $7 \mathrm{a}(33.4 \mathrm{mg}, 60 \%, 64 \%$ ee) as a colorless oil. $R_{\mathrm{f}}=0.3$ (ethyl acetate/nhexane $=1 / 2$ ); ${ }^{1} \mathrm{H}$ NMR $\left(400 \mathrm{MHz} \mathrm{CDCl}_{3}\right) \delta: 2.25-2.35(\mathrm{~m}, 2 \mathrm{H}), 2.83(\mathrm{~s}, 3 \mathrm{H}), 2.92(\mathrm{~s}, 1 \mathrm{H})$, $3.54(\mathrm{~s}, 2 \mathrm{H}), 3.75(\mathrm{~s}, 3 \mathrm{H}), 4.12(\mathrm{~d}, J=11.7,1 \mathrm{H}), 4.29$ (d, $J=11.7$, $1 \mathrm{H}), 5.10-5.14(\mathrm{~m}, 2 \mathrm{H}), 5.78-5.88(\mathrm{~m}, 1 \mathrm{H}), 6.57(\mathrm{~s}, 1 \mathrm{H}), 6.80(\mathrm{~d}, J$ $=8.8,2 \mathrm{H}), 7.06-7.10(\mathrm{~m}, 1 \mathrm{H}), 7.17(\mathrm{~d}, J=8.8,2 \mathrm{H}), 7.29-7.35(\mathrm{~m}$, $4 \mathrm{H}) ;{ }^{13} \mathrm{C} \mathrm{NMR}\left(100 \mathrm{MHz}, \mathrm{CDCl}_{3}\right) \delta: 35.4,37.5,55.3,62.0,63.0$, 65.2, 113.6, 118.7, 123.7, 129.1, 129.2, 133.4, 137.5, 141.8, 157.1; HRMS (EI) calcd for $\mathrm{C}_{21} \mathrm{H}_{26} \mathrm{~N}_{2} \mathrm{O}_{4}\left(\mathrm{M}-\mathrm{C}_{3} \mathrm{H}_{5} \mathrm{O}_{2}\right)^{+} 370.1893$, found 370.1905; HPLC (Daicel Chiralpak $\mathrm{AD}$, flow rate $=1.0$ $\mathrm{mL} \min ^{-1}, n$ hexane/iPrOH $=30 / 1$, detection at $254 \mathrm{~nm}$, set temperature $35^{\circ} \mathrm{C}$ ).

\section{Conflicts of interest}

There are no conflicts to declare.

\section{Acknowledgements}

This work was supported by Grants-in-Aid for Scientific Research (B) and on Innovative Areas "Organic Synthesis Based on Reaction Integration. Development of New Methods and Creation of New Substances" from JSPS and MEXT.

\section{Notes and references}

1 For reviews of $\alpha, \alpha$-disubstituted amino acids, see: $(a)$ C. Cativiela and M. D. Diaz-de-Villegas, Tetrahedron: Asymmetry, 1998, 9, 3517-3599; (b) C. Cativiela and M. D. Diaz-de-Villegas, Tetrahedron: Asymmetry, 2000, 11, 645-732; (c) C. Spino, Angew. Chem., Int. Ed., 2004, 43, 1764-1766; (d) Y. Ohfune and T. Shinada, Eur. J. Org. Chem., 2005, 5127-5143; (e) H. Vogt and S. Brase, Org. Biomol. Chem., 2007, 5, 406-430; $(f)$ M. I. Calaza and C. Cativiela, Eur. J. Chem., 2008, 3427-3448; (g) C. Cativiela and M. Ordóñez, Tetrahedron: Asymmetry, 2009, 20, 1-63.

2 For synthesis of $\alpha, \alpha$-disubstituted amino acids, see the followings. Alkylation of enolate: (a) Y. N. Belokon, R. G. Davies and M. North, Tetrahedron Lett., 2000, 41, 7245-7248; (b) Y. N. Belokon, D. Bhave, D. D'Addario, E. Groaz, V. M. North and A. Pertrosyan, Tetrahedron Lett., 2003, 44, 2045-2048; Alkylation of cyclic compounds: (c) R. M. Williams and M.-N. Im, J. Am. Chem. Soc., 1991, 113, 9276-9286; (d) D. B. Berkowitz, J. M. McFadden, E. Chisowa and C. L. Semerad, J. Am. Chem. Soc., 2000, 122, 11031-11032; Asymmetric Strecker reaction: (e) S. Masumoto, H. Usuda, M. Suzuki, M. Kanai and M. Shibasaki, J. Am. Chem. Soc., 2003, 125, 5634-5635; (f) J. Wang, X. Hu, J. Jiang, S. Gou, X. Huang and X. Feng, Angew. Chem., Int. Ed., 2007, 46, 8468-8470; Addition to imino ester: $(g)$ M. Mitani, Y. Tanaka, A. Sawada, A. Misu and Y. Matsumoto, Eur. J. Org. Chem., 2008, 1383-1391; Radical reaction: $(h)$ H. Miyabe, R. Asada and Y. Takemoto, Tetrahedron, 2005, 61, 385-393; Memory of chirality: (i) T. Kawabata, T. Wirth, K. Yahiro, H. Suzuki and K. Fuji, J. Am. Chem. Soc., 1994, 116, 10809-10810; (j) K. Fuji and T. Kawabata, Chem.-Eur. J., 1998, 4, 373-376; (k) T. Kawabata, J. Chen, H. Suzuki, Y. Nagae, T. Kinoshita, S. Chancharunee and K. Fuji, Org. Lett., 2000, 2, 38833885; (l) T. Kawabata, S. Kawakami and K. Fuji, Tetrahedron Lett., 2002, 43, 1465-1467; Mitsunobu reaction: (m) J. E. Green, D. M. Bender, S. Jackson, M. J. O'Donnell and J. R. McCarthy, Org. Lett., 2009, 11, 807-810; Sigmatropic rearrangement: (n) J. C. Anderson and S. Skerrat, J. Chem. Soc., Perkin Trans. 1, 2002, 2871-2876; Beckmannn rearrangement: (o) R. P. Frutos and D. M. Spero, Tetrahedron Lett., 1998, 39, 2475-2478; Asymmetric hydrolysis: ( $p$ ) V. Iosub, A. R. Haberl, J. Leung, M. Tang, K. Vembaiyan, M. Parvez and T. G. Back, J. Org. Chem., 2010, 75, 1612-1619. 
3 E. J. Corey, D. Y. Gin and R. S. Kania, J. Am. Chem. Soc., 1996, 118, 9202-9203.

4 A. Endo and S. J. Danishefsky, J. Am. Chem. Soc., 2005, 127, 8298-8299.

5 A. S. Kende, K. Kawamura and R. J. DeVita, J. Am. Chem. Soc., 1990, 112, 4070-4072.

6 (a) K. Maruoka, E. Tayama and T. Ooi, Proc. Natl. Acad. Sci. U.S.A., 2004, 101, 5824-5829; (b) C. Toniolo, F. Formaggio, B. Kaptein and Q. B. Broxterman, Synlett, 2006, 1295-1310; (c) K. Tomohara, T. Yoshimura, R. Hyakutake, P. Yang and T. Kawabata, J. Am. Chem. Soc., 2013, 135, 13294-13297; (d) K. Bera and I. N. N. Namboothiri, Asian J. Org. Chem., 2014, 3, 1234-1260; (e) A. E. Metz and M. C. Kozlowski, J. Org. Chem., 2015, 80, 1-7.

7 For $C$-alkylation to $\alpha$-imino esters, see: $(a) \mathrm{J}$.-C. Fiaud and H. B. Kagan, Tetrahedron Lett., 1970, 21, 1813-1816; (b) L. M. Harwood, K. J. Vines and M. G. B. Drew, Synlett, 1996, 1051-1053; (c) D. Ferraris, B. Young, T. Dudding and T. Lectka, J. Am. Chem. Soc., 1998, 120, 4548-4549; (d) A. Córdova, W. Notz, G. Zhong, J. M. Betancort and C. F. Barbas III, J. Am. Chem. Soc., 2002, 124, 1842-1843; (e) K. P. Chiev, S. Roland and P. Mangeney, Tetrahedron: Asymmetry, 2002, 13, 2205-2209; (f) P. Wipf and C. R. J. Stephenson, Org. Lett., 2003, 5, 2449-2452; $(g)$ M. Mitani, Y. Tanaka, A. Sawada, A. Misu and Y. Matsumoto, Eur. J. Org. Chem., 2008, 1383-1391; (h) P. Fu, M. L. Snapper and A. H. Hoveyda, J. Am. Chem. Soc., 2008, 130, 5530-5541; (i) S. Fustero, N. Mateu, L. Albert and J. L. Aceña, J. Org. Chem., 2009, 74, 4429-4432; (j) K. Yeung, F. Talbot, G. P. Howell, A. P. Pulis and D. J. Procter, ACS Catal., 2019, 9, 1655-1661.

8 For $N$-alkylation to $\alpha$-imino esters, see: $(a)$ J.-C. Fiaud and H. B. Kagan, Tetrahedron Lett., 1971, 12, 1019-1022; (b) Y. Yamamoto and W. Ito, Tetrahedron, 1988, 44, 5415-5423; (c) K. Uneyama, F. Yan, S. Hirama and T. Katagiri, Tetrahedron Lett., 1996, 37, 2045-2048; (d) S. E. Yoo and Y. D. Gong, Heterocycles, 1997, 45, 1251-1255; (e) M. P. Bertrand, L. Feray, R. Nouguier and P. Perfetti, Synlett, 1999, 1148-1150; ( $f$ ) M. Mae, H. Amii and
K. Uneyama, Tetrahedron Lett., 2000, 41, 7893-7896; $(g)$ K. P. Chiev, S. Roland and P. Mangeney, Tetrahedron: Asymmetry, 2002, 13, 2205-2209; (h) J. S. Dickstein, M. W. Fennie, A. L. Norman, B. J. Paulose and M. C. Kozlowski, J. Am. Chem. Soc., 2008, 130, 1579415795; (i) J. S. Dickstein and M. C. Kozlowski, Chem. Soc. Rev., 2008, 37, 1166-1173; (j) J. M. Curto, J. S. Dickstein, S. Berritt and M. C. Kozlowski, Org. Lett., 2014, 16, 19481951.

9 (a) Y. Niwa, K. Takayama and M. Shimizu, Bull. Chem. Soc. Jpn., 2002, 75, 1819-1825; (b) Y. Niwa and M. Shimizu, J. Am. Chem. Soc., 2003, 125, 3720-3721; (c) M. Shimizu, H. Itou and M. Miura, J. Am. Chem. Soc., 2005, 127, 32963297; (d) I. Mizota and M. Shimizu, Chem. Rec., 2016, 16, 688-702; (e) I. Mizota, Y. Tadano, Y. Nakamura, T. Haramiishi, M. Hotta and M. Shimizu, Org. Lett., 2019, 21, 2663-2667; $(f)$ M. Shimizu, H. Imazato, I. Mizota and Y. Zhu, RSC Adv., 2019, 9, 17341-17346.

10 (a) T. Miyazawa, Amino Acids, 1999, 16, 191-213; (b) P. D. Maria, B. Kossmann, N. Potgrave, S. Buchholz, H. Trauthwein, O. May and H. Gröger, Synlett, 2005, 17461748; (c) A. Ghanem, Tetrahedron, 2007, 63, 1721-1754; (d) A. C. L. de Melo Carvalho, T. de Sousa Fonseca, M. C. de Mattos, M. C. de Oliveira, T. L. G. de Lemos, F. Molinari, D. Romano and I. Serra, Int. J. Mol. Sci., 2015, 16, 2968229716.

11 (a) G. Desimoni, G. Faita and K. A. Jørgensen, Chem. Rev., 2006, 106, 3561-3651; (b) K. Matsumoto, M. Mitsuda, N. Ushijima, Y. Demizu, O. Onomura and Y. Matsumura, Tetrahedron Lett., 2006, 47, 8453-8456; (c) O. Onomura, M. Mitsuda, M. T. T. Nguyen and Y. Demizu, Tetrahedron Lett., 2007, 48, 9080-9084; (d) A. R. Silva, L. Carneiro, A. P. Carvalho and J. Pires, Catal. Sci. Technol., 2013, 3, 2415-2424.

12 B. K. Banik, M. S. Manhas, E. W. Robb and A. K. Bose, Heterocycles, 1997, 44, 405-415.

13 K. Oka and S. Hara, Tetrahedron Lett., 1977, 18, 2939-2942. 14 A. K. Bose, M. Tsai and J. C. Kapur, Tetrahedron Lett., 1974, 15, 3547-3548. 